\title{
On Enhancing EFL Learner Autonomy in Chinese College English Classroom System
}

\author{
Huanhuan Ren ${ }^{1, a}$, Chi Ma ${ }^{2, b}$ \\ ${ }^{1}$ Teaching and Research Institute of Foreign Languages, Bohai University, Jinzhou 121013, China; \\ ${ }^{2}$ Jinzhou Institute of Forestry Research, Jinzhou Forestry Bureau, Jinzhou 121013, China. \\ arenhuanhuan2014@163.com, 'bmachi2014@tom.com
}

Keywords: EFL, learner autonomy, Chinese college English classroom.

\begin{abstract}
Learner autonomy has been a major area of interest in EFL teaching in China for so many years. Evidence from this study shows there are various needs for EFL learning in Chinese college English classroom system and some insights into it have been revealed. It's suggested that strategies on enhancing EFL learner autonomy including changes in learning beliefs and strategies of EFL learners, access to cooperative activities for EFL learners, provision of formative assessment for EFL learners, and use of rich resources by EFL learners be integrated into the regular curriculum of Chinese college English classroom system. It's hoped that this move could serve some linguistic purpose in addition to learner development in EFL learning process.
\end{abstract}

\section{Introduction}

Learner autonomy has been a major area of interest in EFL (English as foreign language) teaching in China for so many years. This paper details one study conducted in an EFL classroom in China where learner autonomy is needed to be improved at large. The variuos needs for EFL learning in Chinese college English classroom system are presented in this thesis. Besides, this study is also an attempt to investigate the specfic strategies on enhancing EFL learner autonomy in Chinese college English classroom system. This paper is a summary of this research work, which hopefully provides a useful reference for future autonomous learning among EFL learners.

\section{Developments of Learner Autonomy in EFL Learning}

Learner Autonomy. The research pertinent to learner autonomy (abbreviated to LA) has long been conducted in various fields; however, it's still a difficult concept to define. One explanation of this is that learner autonomy is a multidimensional construct of capacity that will take different forms for different individuals, and even for the same individual in different contexts and at different times[1]. In other words, learner autonomy carries multiple meanings with different interpretations of the autonomous self. The classic definition of learner autonomy is "the ability to take charge of one's own learning”, given by Holic (a leading figure within this field)[2]. According to Dickinson, learner autonomy is "the situation in which the learner is totally responsible for all of the decisions concerned with his learning and the implementation of those decisions"[3]. However, Benson argued that it is insufficient to view learner autonomy as self management of learning (as asserted by Holic) or learner responsibility (as advocated by Dickinson), and added learning content as a third aspect of learner autonomy, which means learning situations in which learners have the right to make decisions about their learning[4]. From above, the key idea emerging from those definitions is the learner's capacity, responsibility and right to control over the whole learning process.

LA in EFL Learning. Learner autonomy has been a major area of interest in foreign language (FL) teaching and has been paid a lot of attention generally and particularly in English as foreign language (EFL) learning field. In this regard, a significant body of research about learner autonomy in EFL has been undertook both at home and abroad, and gives much insights into the effective EFL learning and instruction in China. It's found that learner autonomy potentially has a great impact on personal 
growth and achievement, and is a huge assistance for the cultivation of all-around skills in EFL learning. In the past, however, what the learners do, and how they do it was largely determined by an authority figure i.e. the teacher, as opposed to the learner. This traditional learning approach features low efficiency in EFL learning, and is detriment to the development of EFL learner autonomy. It's suggested that learners be freed from the complete dependence on teachers by taking much more responsibilities for their learning. In a word, EFL learning is best achieved if students play an active role in the process, and the cultivation of learner autonomy in EFL learning is part of the move that may contribute to the aim of an "education towards autonomy".

EFL Learners for LA. What kinds of EFL learners are claimed to be EFL autonomous learners? A list of characteristics that EFL autonomous learner have to have should be outlined and specified. Learners are suggested to get to know what, how, and when to learn English language. In Benson's study, autonomous learners are assumed to take control over their learning management, cognitive process, and learning content. Specially speaking, control over learning management involves self-management of learning in which learners are assumed to plan, organize, and evaluate their learning with learning strategies; control over cognitive process consists of attention or awareness, reflection, and metacognitive knowledge; control over learning content means the negotiation for the right to make decision about their learning[5]. According to David Nunan, common characteristics for people who successfully and dramatically improved their language skills through learning autonomously are outlined in a more detailed way, including a diversity of skills, passion and enjoyment for a particular field, a focused and active approach to learning, and finally, pursuit of learning and success. [6] In short, characteristics and abilities of learner autonomy should be cultivated so that EFL learners are more likely to make significant decisions and take proactive actions in EFL learning process.

\section{Insights into EFL Learning in Chinese College English Classroom Context}

The Reasons for College English. College English, an integral part of higher learning, is a required basic course for undergraduate students in Chinese context. Then why do college students learn college English course? It's proved that college English has much to offer. Here are several good and compelling reasons for college students to take a college English course. Firstly, English is the most popular language around the world, and mastering English language is good for communication and cooperation in the international scenarios. As we know, one out of five people can speak or at least understand English, so students who are working towards mastery of college English can reach out for a rich wealth of information and take part in various social interactions. Besides, college English courses provide language learners more opportunities for future studies and careers. In other words, students with high command of English language are more likely to get a good job in a multinational company within home country. What's more, general cultural awareness of learners should also be enhanced through learning college English, as few experiences will make learners grow as persons more than learning the values, habits and way of life in a culture that is different from theirs. In a word, English has been described as "the language of opportunity", and learners will be provided with more possibilities and potentials through taking college English courses in Chinese context.

Autonomy in College English Classroom. The link between learner autonomy and effective learning has inevitably led to various pedagogical attempts to foster learner autonomy in Chinese context. Learner autonomy has been claimed to be an ultimate goal of education for a long time, and one of the objectives of college English learning is to promote the development of individualized study methods and the autonomous learning ability on the part of students. Just as College English Curriculum Requirements puts, "changes in the teaching model by no means call for changes in teaching methods and approaches only, but, more important, consist of changes in teaching philosophy and practice, and in a shift from a teacher-centered pattern, in which knowledge of the language and skills are imparted by the teacher in class only, to a student-centered pattern, in which the ability to use the language and the ability to learn independently are cultivated in addition to language knowledge and skills, and also to lifelong education, geared towards cultivating students 
lifelong learning ability"[7]. All in all, the incorporation of autonomy in the college English curricula in china has led to learner-based approaches in classroom aiming at the development of English language proficiency and EFL learner autonomy.

\section{Strategies on Enhancing EFL Learner Autonomy in Chinese College English Classroom System}

Changes in Learning Beliefs and Strategies of EFL Learners. Instructors should make a shift in learners' believes about language and language learning. EFL learners are expected to be informed that learning a language is for the sake of communicative skills as opposed to graduation requirement, and language learning is an rewarding and enjoyable learning experience, and should be learned with interest and motives, and should also be conducted under the control of learners themselves. EFL learners ought to execute learner autonomy in learning practice. Besides, various activities should be carried out in classroom to raise student awareness of various aspects of learning strategies, including metacognition, socio-cultural strategies, etc. Teachers could foster an awareness of the skills that are involved in learning, and demonstrate the learning strategies in use through the activities that they plan during the course. All in all, to reach the goal of autonomy, EFL learners need to be provided with the knowledge on how to learn, how to exercise self-control, and how to develop their learning potentials.

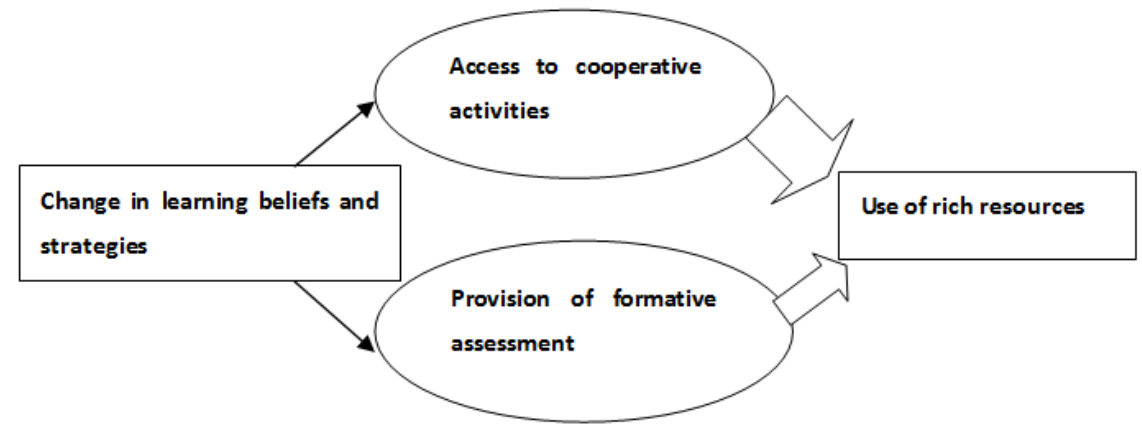

Fig.1. Pedagogical strategies on enhancing EFL learner autonomy

Access to Cooperative Activities for EFL Learners. To build EFL learner autonomy in the class, instructors should evoke EFL learners' willingness to cooperate with others through interaction and collaboration in presence of others in the classroom. Although Chinese EFL learners are generally cooperative, they do not seem to be willing to do more than the minimum. And some learners in China are wary about taking these risks, so they are satisfied simply with the limited exposure that they get in large EFL classrooms. One method that is often recommended to students looking to improve their communicative skills is to engage in learning activities. In other words, classroom pedagogy should not be conducted in the form of one-way transferring knowledge from teachers to learners, but rather through various activities involving mutual dialogues or group discussion among learners. Besides, it's believed that some guidelines for successful interactions need to be given to learners. In brief, EFL teachers are considered to create and maintain learning community by providing cooperative activities for EFL learners.

Provision of Formative Assessment for EFL Learners. Classroom is not only a place for be oneself but also a place of reflecting oneself, which can make the EFL learning more rewarding and meaningful. Coupled with summative assessment, formative assessment ought to be conducted in the process of learning, aimed at increasing performance and reflection of EFL learners. It can be conducted among teacher, learners and peers and in the form of oral statement or written assessment. The feedback should be delivered timely and effectively. Some students may need more time to digest what they have learnt and it may take them longer to think and write about their feelings and thoughts. In this regard, more help should be given to them. As for the content of feedback, both positive and negative feedback should be paired to help EFL learners. Instructors can do that openly or secretly according to specific situation. Being able to critically reflect on one's learning experience is a skill that takes time and practice to learn. All in all, formative assessment should be incorporated 
and integrated into classroom as reflection on their feedback enabled learners to better plan learning activities and to choose more appropriate materials and methodologies for them.

Use of Rich Resources by EFL Learners. How to construct the knowledge or information learned in the class, or how to extend the knowledge already learned? Instructors are expected to not only teach a language, but to also inform and instruct how to study outside the classroom. With a wealth of resources available for self-study through multimedia and the Internet, language teaching is, now more than ever before, in a position to encourage learner autonomy. Resources can be offered in many forms, but convenient and relevant, and at the control of learners. This will be accomplished by presenting tasks that inspire the learner to take learning into their own hands. One may say that it's important for the instructor to encourage homework assignments that will force students to explore realms and means in autonomous learning. However, the truth is that it's not necessarily a desired assignment, but just a reference for those who what to learn. In sum, rich resources should be recommended to learners for learner autonomy as autonomy requires accumulating a diverse set of resources that will maximize exposure and improvements in EFL learning.

\section{Summary}

Evidence from this study shows there are various needs for EFL learning in Chinese college English classroom system and some insights into it have been revealed. It's suggested that strategies on enhancing EFL learner autonomy including changes in learning beliefs and strategies of EFL learners, access to cooperative activities for EFL learners, provision of formative assessment for EFL learners, and use of rich resources by EFL learners be integrated into the regular curriculum of Chinese college English classroom system. It's hoped that this move could serve some linguistic purpose in addition to learner development in EFL learning.

\section{Acknowledgement}

This work is part of the project of On Cultivating and Developing Liaoning Scientific Foreign Language Talents with View to Bourdieu' Theory, the project of On Establishing Generative Mechanism of EFL Autonomous Learning Behaviors and Strengthening Development of Learning Field in Ubiquitous Learning Space, and the project of On Constructing Mechanism and Strategies for College English Autonomous Learning Abilities via Mobile Multimedia. This research was supported by the fund of Liaoning Planning of Philosophy and Social Science (Project No. L16CYY001), the fund of Liaoning Provincial Federation Social Science Circles (Project No. 2017lslktyb-019), and the fund of the Thirteenth Five-Year Plan of Education Sciences of Liaoning Province (Project No. JG16DB013).

\section{References}

[1][4][5] P. Benson, Teaching and Researching Autonomy in Language Learning, Lonsdon: Longman, 2001

[2]H. Holic, Autonomy and foreign language learning. Oxford: Pergamon, 1981.

[3]L. Dickinson, Self-instruction in Language Learning, Cambridge: Cambridge University Press, 1987.

[6]D. Nunan, Autonomy in Language Learning. Retrieved from April 29th, 2008 http://www.nunan.info/presentations/autonomy_lang_learn.pdf

[7][8][9]Ministry of Education of the People's Republic of China, College English Curriculum Requirements. Beijing: Higher Education Press, 2007. 